\title{
Profitability, Liquidity, and Firm Value: Does Financial Distress Have a Mediating Effect? (Study of Manufacturing Companies in Indonesia)
}

\author{
Melinda Dewi ${ }^{1, *}$ Gabriella Natasya Foanto ${ }^{1}$ Yulius Jogi Christiawan ${ }^{1}$ \\ ${ }^{I}$ Department of Business Accounting, Petra Christian University, Surabaya, Indonesia \\ *Corresponding Author. E-mail: melindadewi.bali@gmail.com
}

\begin{abstract}
Profitability and liquidity are essential factors in investor evaluation. The increased profitability and liquidity value reduces the risk of a company going bankrupt. This study examines the role of financial distress in the relationship between profitability and liquidity. The research looked at 170 industrial companies listed on IDX for 2016-2020. The data were analyzed using PLS (Partial Least Square). Profitability and Firm Value are perfectly mediated by financial distress, with Liquidity as the independent variable. The study's major finding is that profitability and liquidity have no direct impact on firm value, but financial distress does. Signal theory states that information about financial circumstances that are not in financial distress might encourage investors to invest, hence increasing Firm Value. This research contributes to the literature on the impact of Financial Distress in predicting the influence of Profitability and Liquidity on boosting Firm Value.
\end{abstract}

Keywords: Financial distress, Financial performance, Firm value, Liquidity, Profitability.

\section{INTRODUCTION}

The number of start-up companies that have emerged show that development and competition in the business world are getting tougher, thus requiring companies to continue to compete in maintaining a stable and increasing value. Company value is one of the important aspects that must be built by the company because the value of the company represents the success level of the company.

The company's financial performance can be evaluated. Financial performance seeks to determine the company's financial position using financial ratios. This study uses profitability and liquidity ratios to assess the company's potential to produce profits and monitor its operational and financial activities [1]. Liquidity can be used to determine debt repayment ability [2]. The more liquid the company, the better for investors.

Firm Value is unaffected by profitability, according to studies [3]; [4]. However, [5] observed a positive correlation between Profitability and Firm Value since the stock price rises when the company makes a lot of money. Although the association between Liquidity and Firm Value was shown to be positively linked in [6], the relationship between Liquidity and Firm Value was found to be negatively linked in [7].

Profitability and liquidity can also forecast a company's financial health. A corporation in financial trouble is at risk of bankruptcy [8]. Companies that have poor performance indicate that the profits generated are not sufficient to meet their obligations, so the lower Profitability and Liquidity, the higher potential that company will experience Financial Distress.

Because of the inconsistent results, purpose of this study is to further examine the relationship between Profitability, Liquidity and Firm Value by adding Financial Distress as a mediating variable because it is an illustration of the company's financial condition, which is an effective method for investors to see the company's condition. 
Manufacturing companies were chosen to be the research sample because they are one of the sectors that have many sub-sectors of companies and have sustainable production, so that they have more assets than other sectors in accordance with the Profitability and Liquidity variables that use assets as the basis for calculations.

\section{LITERATURE REVIEW \& HYPOTHESIS DEVELOPMENT}

\subsection{Theoretical Framework}

\subsubsection{Agency Theory}

Agency theory is a theory where the principal and agent have different interests so that there is a conflict of interest and information asymmetry where the information obtained by management is more than the principal because management has direct involvement in the company [9]

The relationship between agency theory and all variables is that management has responsibilities to external parties in the form of financial performance disclosures such as Profitability and Liquidity which are contained in financial statements as consideration in making decisions. However, the information presented is not always available and can be hidden, resulting in losses for the principal [10].

\subsubsection{Signaling Theory}

Information about a company is provided to investors and other stakeholders as part of the signal theory process. This theory also shows how management acts and guides investors in evaluating a firm [11]. Producing quality financial reports will reduce knowledge asymmetry between agents and principals [12].

The relationship between signal theory and all variables is the availability of good information, which helps investors assess the company's potential to create profits and meet its responsibilities. Increasing profitability and liquidity reduces the likelihood of a company going bankrupt, which benefits investors by improving the company's reputation, price, and share count, so increasing the firm's value Figure 1.

\subsection{Relationship Between Variables}

There are 4 variables in this study, which is Profitability symbolized by PROF and Liquidity symbolized by LQD as the independent variable, Firm value symbolized by FV as the dependent variable, and Financial Distress symbolized by FND as the intervening variable.

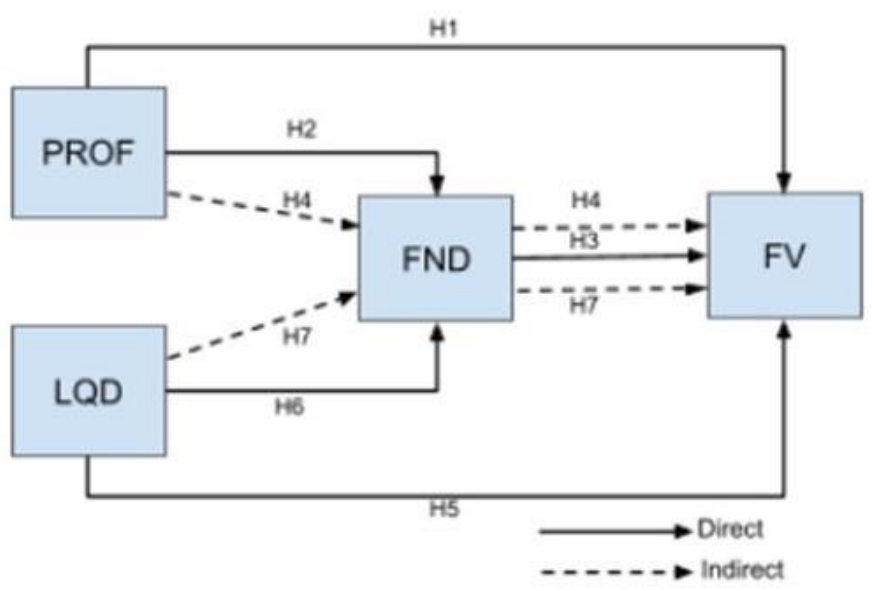

Figure 1. Research Model

Profitability is a ratio of investment to sales or income [12]. Profitability can reflect a company's capacity to create profits and manage its assets properly. Cash flow is a measure of a company's liquidity [13]. Current assets and liabilities like as cash, receivables, inventory, short-term debt, bonds, etc. generate liquidity. Financial distress occurs when a corporation is unable to meet its obligations due to a lack of profits. It is an investor's assessment of the company's success [13]. The company's purpose is to increase Firm Value for the company and shareholders [14].

\subsubsection{PROF and FV}

PROF has an important role in companies that become a benchmark for investors in assessing the company and the company's prospects in the future, so that if the PROF value increases, it will also increase FV. In accordance with signal theory, information related to the company's PROF value will be a positive or negative signal for investors in making investment decisions. The increase in PROF will also minimize agency costs that arise due to information asymmetry in agency theory.

Reference [14] suggested that PROF has a significant positive relationship to $\mathrm{FV}$ because PROF can show the level of profit generated by the company which will later be distributed to shareholders in the form of returns and dividends, so it can be said that higher PROF will cause an increase in FV which is reflected by rising stock prices. These results are in line with [17] which found that PROF has a positive and significant relationship to $\mathrm{FV}$, because investors in making decisions will look at the company's PROF value to assess whether the assets owned can be used effectively and the profits earned have been maximum or not. So that the hypothesis can be determined as follows:

$\mathrm{H}_{1}$ : PROF has a positive effect on FV. 


\subsubsection{PROF and FND}

Based on agency theory, PROF can play a role in reducing conflict because it provides information for external parties who can find out the condition of the company [9]. By knowing the condition of the company, we can find out how much profit is generated and how effective is the management of company assets. The higher PROF value, the better asset management in generating profits, so the risk of FND is lower. Because the high profit generated indicates that the company has sufficient funds to meet and pay its obligations. On the other hand, the lower PROF means the higher probability of FND because the company does not have sufficient funds to pay its obligations.

[15] found that PROF had a negative effect on FND. This study is in line with [19] which found that PROF has a significant negative effect on FND because PROF as measured by ROA can show how the company's financial condition is. So that the hypothesis can be determined as follows:

\section{$\mathrm{H}_{2}$ : PROF has a negative effect on FND.}

\subsubsection{FND and FV}

The high FND value indicates that the company is experiencing financial difficulties so that it cannot pay its obligations. This is a concern for investors to assess whether the target company is healthy or not. Investors will certainly ensure that the target company is free from financial problems and has reliable financial and non-financial activities.

Thus, if the company's FND is higher, the FV will be lower because investors will not invest in high-risk companies that also cannot fulfill their obligations. So that the hypothesis can be determined as follows:

$\mathrm{H}_{3}$ : FND has a negative effect on FV.

\subsubsection{PROF, FND and FV}

Based on signal theory, PROF is information that must be provided by the company. [16] A high PROF will improve the quality of financial reports which have an impact on increasing profits and the company's stock price. This is a positive signal for investors to the company in investing activity. Information about the financial condition is related to the PROF value so that, by knowing the PROF value, we can have an idea of whether the company is experiencing FND or not. FND information will be useful for investors so that investors do not only look at the profit side, but also from the company's financial condition. So that the hypothesis can be determined as follows:

$\mathrm{H}_{4}$ : FND mediates the relationship between PROF and FV.

\subsubsection{LQD and $F V$}

Liquidity, which is also a financial ratio, has a role in the company's success [17] LQD can provide information on the company's ability to pay its current obligations. The higher LQD, the higher FV will be, because it reflects that the company is in a good condition [15] In accordance with the signal theory, that company information can provide a signal to investors. Companies that are liquid, show that the company is able to pay its short-term debt so that it will be a positive signal for investors. It can be concluded that the high value of LQD will cause FV to increase.

[18] found that LQD has a significant positive relationship with FV because the value of LQD provides information regarding the availability of funds to pay all current liabilities which causes investor's perceptions of good companies and FV will increase. So that the hypothesis can be determined as follows:

$\mathrm{H}_{5}$ : Liquidity has a positive effect on FV.

\subsubsection{LQD and FND}

LQD symbolizes the company's ability to meet its shortterm obligations. LQD can reduce conflicts that occur according to agency theory. The availability of information for all parties will reduce the occurrence of information asymmetry between the agent and the principal. The availability of information regarding LQD allows the market to see how the company's ability to meet its current obligations is.

If the corporation has more current assets than current liabilities, it is in a liquid position, according to [19]. Because of this, it is possible for the corporation to avoid the likelihood of a FND in this current era with a high LQD [8]. [20] discovered that LQD has a negative impact on FND since it implies that the company is able to pay off its present debts, which means that the likelihood of the company experiencing FND will be reduced. So that the hypothesis can be determined as follows:

$\mathrm{H}_{6}$ : LQD has a negative effect on FND.

\subsection{7. $L Q D$, $F N D$ and $F V$}

FND is a benchmark for investors in making investment decisions because it can reflect the company's financial condition. A small FND indicates that the company is not in a difficult financial condition, thus attracting investor interest and confidence in the company with the assumption that the company will be going concern, also able to provide high returns and dividends as well. The increasing number of investors in the company will cause the number and price of shares to increase as well as the value of the company itself. 
[21] The results of research found that LQD had a negative effect on FND. This means that the higher LQD ratio, the lower chance of a company experiencing FND. So that the hypothesis can be determined as follows:

$\mathrm{H}_{7}$ : FND mediates the relationship between Liquidity and FV.

\section{METHOD}

\subsection{Data Selection and Collection}

The type of data used in this study is quantitative data using secondary data in the form of company financial statements obtained from the Bloomberg and IDX websites.

\subsection{Population and Sample}

170 manufacturing companies listed on the IDX for 2016-2020 was taken as the research sample, using a purposive sampling technique based on the following criteria: 1). Manufacturing companies that are listed on the IDX and are not delisted during 2016-2020, 2). The company uses Rupiah as the currency in the presentation of financial statements, 3). The company experienced and reported profits during 2016-2020,4). The company issued financial statements for 2016-2020 which ended on December 31, 5). The company has a Z-Score < 6, and 6). The company has a complete and reliable data.

\subsection{Measurement and Operational Definition of Variables}

\subsubsection{Firm Value}

FV was measured using the Tobin's $Q$ formula to find out the company's performance through the company's growth and development opportunities in investment activities as well as market assessment of the company's prospects. $\mathrm{FV}$ is generated from the calculation of a company's market value of equity and book value of debt, divided by the company's total assets. Formulated as follows:

$$
\mathrm{FV}=\left[\left(\left(\mathrm{P}^{*} \mathrm{Q}\right)+\text { Debt }\right) / \text { Total Assets }\right]
$$

Information:

$\mathrm{FV}=$ Firm Value

$\mathrm{P}=$ Closed price

$\mathrm{Q}=$ Number of shares outstanding

Debt $=$ Book value of Total Debt

$\mathrm{TA}=$ Total Assets

\subsubsection{Financial Distress}

FND in this study was measured using the Altman ZScore to calculate the financial difficulties or economic failure experienced by the company, as well as predict the risk of company bankruptcy. Using a special method to calculate manufacturing companies that formulated as follows:

$$
\begin{gathered}
\mathrm{FND}=(1.2 * \mathrm{X} 1)+(1.4 * \mathrm{X} 2)+(3.3 * \mathrm{X} 3)+(0.6 * \mathrm{X} 4) \\
+(0.99 * \mathrm{X} 5)
\end{gathered}
$$

Information:

FND $=$ Total Index

$\mathrm{X} 1=$ Working Capital/Total Assets

$\mathrm{X} 2=$ Retained Earnings/Total Assets

X3= Earnings Before Interest and Taxes/Total Assets

X4= Market Value of Equity/Total Liability

X5 $=$ Sales/Total Assets

\subsubsection{Profitability}

PROF in this study was measured using the Return on Asset (ROA) formula to determine a company's ability to utilize its assets to generate profits and the rate of return from asset investment activities, especially in fixed assets. PROF is formulated with the following formula:

$\mathrm{PROF}=$ Net Income $/$ Total Assets

\subsubsection{Liquidity}

A company's ability to pay its short-term debt is determined using the Current Ratio calculation. In order to calculate a company's current ratio, it looks at how many current assets the company has available to cover its shortterm debts. Current Ratio can be formulated with the following formula:

\section{LQD $=$ Current Asset / Current Liabilities}

\subsection{Data Analysis Method}

To find out the relationship between Profitability and FV through FND, this study used PLS (Partial Least Square) as data analysis method with the help of SmartPLS application. This method was chosen to see the mediating effect produced by FND through observations on the value of the indirect effect.

\section{RESULTS \& DISCUSSION}

\subsection{Descriptive Statistics}

Show in able 1 it can be seen that the companies used in this study were 170 samples $(\mathrm{N})$. The minimum value of PROF is 0.00 and the maximum value is 0.140 . The average of PROF shows the lowest result compared to the average value of other indicators, which is 0.044 , which means that 
the company's average rate of return in managing its assets is only $4.4 \%$. It

Table 1. Descriptive Statistics

\begin{tabular}{|l|c|c|c|c|c|}
\hline Variable & N & Min & Max & Mean & Std. Deviation \\
\hline PROF & 170 & 0.000 & 0.140 & 0.044 & 0.029 \\
\hline FND & 170 & 0.970 & 5840 & 2,790 & 1,110 \\
\hline FV & 170 & 0.240 & 3.110 & 0.916 & 0.518 \\
\hline LQD & 170 & 0.860 & 6.020 & 1,894 & 0.912 \\
\hline Valid N & 170 & & & & \\
\hline
\end{tabular}

can be said that manufacturing companies are less effective in managing their assets because they have the lowest average value which is only $4.4 \%$.

FND has a minimum value of 0.970 and a maximum value of 5,840. The average of FND shows the highest value compared to other indicators, which is 2.79 , which means the company is in the gray zone because it has a value < 2.99. Even though the companies are not in a distress zone, there is a possibility that the gray zone will move into a distress zone. So, appropriate action is needed for companies to be able to move positions into a safe zone which has a $\mathrm{z}$-score $>=3$.

The minimum LQD value is 0.86 and the maximum value is 6.020. While the average value of LQD is 1,894 which is quite high that reflects the good condition of the company. This proves that the average manufacturing company has a good level of liquidity.

FV has a minimum value of 0.240 and a maximum value of 3.110. While the average value of FV is 0.916 , which means that the average manufacturing industry company has the ability to utilize its assets to earn profits up to almost $1 \mathrm{x}$ of the total assets it has, which is 0.9 times.

\subsection{Outer Model Analysis}

This is used to see the relationship of each indicator towards research variables by testing the validity and reliability of the data used. Outer Model test results are as follows Figure 2.

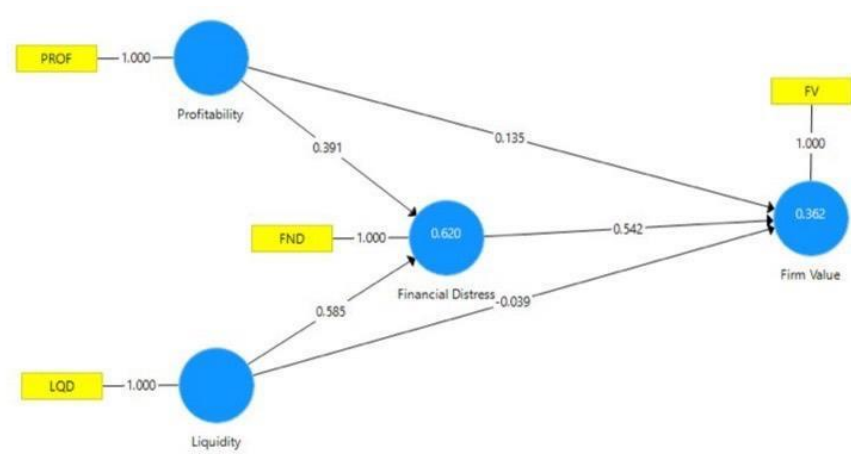

\subsubsection{Reliability and Validity Test}

Reliability and Validity test is conducted to see whether the data used in a study is valid and reliable and to anticipate the possibility of data anomalies show in Table 2 .

Table 2. Construct Reliability and Validity

\begin{tabular}{|l|c|c|c|c|}
\hline \multicolumn{1}{|c|}{ Variable } & $\begin{array}{c}\text { Cronbach's } \\
\text { Alpha }\end{array}$ & rho_A & $\begin{array}{c}\text { Composite } \\
\text { Reliability }\end{array}$ & AVE \\
\hline Liquidity & 1.000 & 1.000 & 1.000 & 1.000 \\
\hline $\begin{array}{l}\text { Financial } \\
\text { Distress }\end{array}$ & 1.000 & 1.000 & 1.000 & 1.000 \\
\hline Firm Value & 1.000 & 1.000 & 1.000 & 1.000 \\
\hline Profitability & 1.000 & 1.000 & 1.000 & 1.000 \\
\hline
\end{tabular}

In the reliability and validity test, there are several tests and the minimum value of each is expected. Cronbach's Alpha is expected to have a value $>0.6$, Composite Reliability is expected to have a value $>0.8$ and AVE is expected to have a value $>0.5$. The AVE value $<0.5$ is considered inadequate because it's unable to explain at least $50 \%$ of the variance of each indicator so that the variable can be considered invalid. Based on the table above, it can be seen that all the variables used in this study have results exceeding the minimum value of each test and prove that all variables are reliable.

Table 3. Cross Loading

\begin{tabular}{|l|c|c|c|c|}
\hline Indicator & Liquidity & $\begin{array}{c}\text { Financial } \\
\text { Distress }\end{array}$ & $\begin{array}{c}\text { Firm } \\
\text { Value }\end{array}$ & Profitability \\
\hline LQD & 1,000 & 0.589 & 0.692 & 0.550 \\
\hline FND & 0.589 & 1,000 & 0.371 & 0.422 \\
\hline FV & 0.692 & 0.372 & 1,000 & 0.272 \\
\hline PROF & 0.550 & 0.422 & 0.272 & 1,000 \\
\hline
\end{tabular}

In the Table 3 it can be seen that the loadings value and the correlation between indicators and its variables are greater than the correlation values between different indicators and variables. Thus, it can be concluded that the tested data is a valid data because it has a greater loading value for each variable and indicator than the loading value between different indicators and variables.

\subsection{Inner Model Analysis}

After analyzing the Outer Model, the observations of the research results are based on the inner model as follows figure 3

Figure 2. Outer Model 


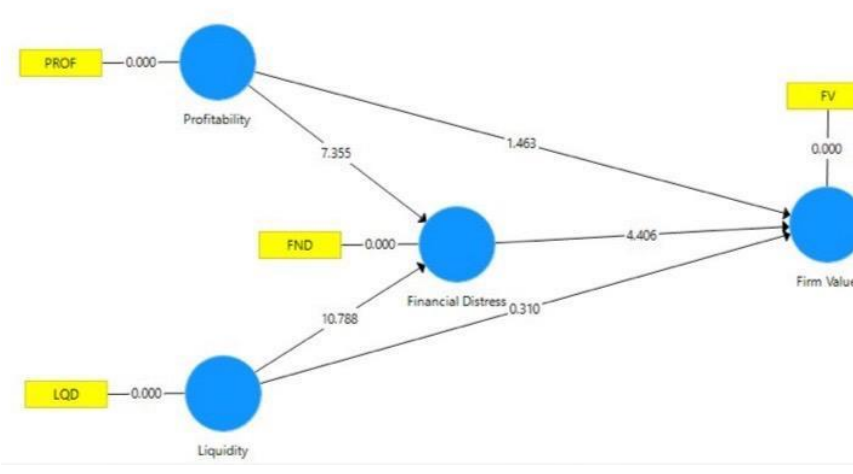

Figure 3. Inner Model

\subsubsection{R-Square}

The R-Square test was used to examine if the independent variable could explain the dependent variable. To get the best performance, the final value should fall anywhere between 0 and 1 . The following are the results of the R-Square test described in the Table 4.

Table 4. R-Square

\begin{tabular}{|l|c|c|}
\hline \multicolumn{1}{|c|}{ Variable } & R-Square & R-Square Adjusted \\
\hline Financial Distress & 0.620 & 0.615 \\
\hline Firm Value & 0.362 & 0.350 \\
\hline
\end{tabular}

It is known that FND has a value of 0.620 , which means that FND is influenced by the independent variables PROF and LQD, and the value of dependent variable FV is $62 \%$, while the other $38 \%$ is explained by other factors outside the variables studied. As well as the FV which has a value of 0.362 , defines that FV is influenced by the independent and intervening variables PROF, LQD and FND is only $36.2 \%$ while the other $63.8 \%$ is explained by other factors outside the variables studied.

\subsection{Hypothesis Test}

\subsubsection{Path Coefficient Analysis}

Table 5. Path Coefficient

\begin{tabular}{|l|c|c|c|c|}
\hline \multicolumn{1}{|c|}{ Indicator } & $\begin{array}{c}\text { Original } \\
\text { Sample }\end{array}$ & $\begin{array}{c}\mathrm{T} \\
\text { Statistics }\end{array}$ & P-Value & Result \\
\hline $\mathrm{PROF} \rightarrow \mathrm{FV}$ & 0.135 & 1.463 & 0.144 & H1 Rejected \\
\hline LQD $\rightarrow$ FV & -0.039 & 0.310 & 0.757 & H5 Rejected \\
\hline $\mathrm{PROF} \rightarrow$ FND & 0.391 & 7.355 & 0.000 & H2 Accepted \\
\hline FND $\rightarrow$ FV & 0.542 & 4.406 & 0.000 & H3 Accepted \\
\hline LQD $\rightarrow$ FND & 0.585 & 10,788 & 0.000 & H6 Accepted \\
\hline
\end{tabular}

In the table 5 show P-values less than 0.05 or t-statistics above 1.96 are required for the hypothesis to be accepted.
Profitability and Firm Value have a t-statistic value of 1.96 and a p-value of 0.144 or above, which means that the association is not significant. According to the value of Original Sample, Profitability and Firm Value have a positive correlation. $\mathrm{H} 1$ is rejected because the association between profitability and firm value is positive but not statistically significant. According to [3] profitability has no impact on the value of a company. In order to attract investors, a company should not only rely on large profits, but it should also look at other variables that can raise Firm Value.

There is no correlation between Liquidity and Firm Value because the t-statistic value is 0.310 or 1.96 and the p-value is 0.757 or $>0.05$, which means the link is not significant. There is a negative correlation between Liquidity and Firm Value based on the original Sample value of -0.039 Liquidity and Firm Value appear to have a negative correlation, but this correlation is not statistically significant, so H5 is discarded. More liquid a corporation is, the more efficient it is at paying its current liabilities using current assets, such as cash or securities. In other words, a high LQD can indicate that the company has big investments that allow obsolescence to occur before the investment is sold, which means that a shareholder does not expect a high LQD value.

The lower a company's Z-score, the less likely it is that it will be in Financial Distress. Altman's Z-score is used to construct the Financial Distress variable. Theoretically, the more financially distressed a company is, the more likely it is that it will suffer financial trouble. As a result, the link between the Z-score formula's proxy variables for financial distress is in conflict with the conceptual formulation it was designed to support.

The t-statistic value of 7355 , or $>1.96$, and p-values of 0.000 or 0.05 show a strong connection between profitability and financial distress. 0.391, the sample's original value, shows a positive number in mathematical computations but a negative number in theory. It can be concluded that there is a significant negative relationship between Profitability and Financial Distress, so $\mathrm{H} 2$ is accepted. The less likely it is that a company will be forced into bankruptcy because of its strong profit margins, which it may use to meet its financial obligations. The company's ability to rise and escape severe financial conditions is demonstrated in part by its ability to maintain a steady profit. According to [10], profitability has a considerable negative impact on Financial Distress, this finding is in agreement. High profit margins imply that management is doing a good job and that investors are reaping the rewards. Profitability rose as a result of the company's effective utilization of assets, resulting in adequate funding and operational efficiency. 
A t-statistic value of 4.406 or greater than 1.96 , and a pvalue of 0.000 or less than five percent, indicate that the association between Financial Distress and Firm Value is significant. Financial distress and firm value have a negative association in theory, based on the Original Sample's value of 0.542 (positive in quantitative calculations). Since the link between Financial Distress and Firm Value is negative, we can conclude that $\mathrm{H} 3$ is accepted.

The t-statistic of 10,788 or $>1.96$ and the p-value of 0.000 or 0.05 between Liquidity and Financial Distress is likewise significant. The initial Sample value of 0.585 is a positive number in mathematics but a negative number in theory. Thus, H6 is accepted because the link between Liquidity and Financial Distress is significant negative. This finding is in line with [10], which demonstrated a negative correlation between Liquidity and Financial Stress. The corporation will avoid the financial crisis if it can pay its short-term obligations.

\subsubsection{Mediation Test}

Mediation Test is conducted to see whether there is a mediating effect of Financial Distress on Profitability and Firm Value, as well as Liquidity and Firm Value or not. The results of the mediation test can be seen in the following Table 6.

\section{Specific Indirect Effects}

Table 6. Total Indirect Effects

\begin{tabular}{|c|c|c|c|c|c|}
\hline Indicator & $\begin{array}{c}\text { Original } \\
\text { Sample }\end{array}$ & Mean & $\begin{array}{c}\mathrm{T} \\
\text { Statistics }\end{array}$ & P-Value & Result \\
\hline $\begin{array}{r}\mathrm{PROF} \rightarrow \\
\text { FND } \rightarrow \text { FV }\end{array}$ & 0.212 & 0.202 & 3,507 & 0.000 & $\begin{array}{c}\mathrm{H} 4 \\
\text { Accepted }\end{array}$ \\
\hline $\begin{array}{r}\mathrm{LQD} \rightarrow \\
\text { FND } \rightarrow \text { FV }\end{array}$ & 0.318 & 0.303 & 4.329 & 0.000 & $\begin{array}{r}\mathrm{H} 7 \\
\text { Accepted }\end{array}$ \\
\hline
\end{tabular}

There is a t-statistic level of significance of 3,507 or > 1.96 for financial distress mediating profitability and firm value. The initial Sample value of 0.212 suggests a positive association. Thus, there is a considerable positive association between Profitability and Firm Value through Financial Distress, proving mediation and accepting $\mathrm{H} 4$.

Financial distress has a considerable mediating influence on liquidity and firm value with t-statistic significance levels of 4,329 or > 1.96 and p-values of 0.000 or 0 . The initial Sample value of 0.318 suggests a positive association. Thus, there is a mediation effect and a substantial positive association between Liquidity and Firm Value through Financial Distress, proving mediation and accepting $\mathrm{H} 7$.
Liquidity and Firm Value can be stated to be perfectly mediated by Financial Distress, as can Profitability and Firm Value. Due to the lack of a direct link between Profitability and Liquidity to Firm Value, Financial Distress will establish an indirect link between Profitability and Liquidity to Firm Value.

\section{CONCLUSION}

Signaling theory provides investors with information about the companies that can provide signals to investors in making investment decisions. The information provided can be in the form of information about the company's financial performance that is presented by the company's Profitability and Liquidity, which will later be a good or bad signal based on the company's Profitability and Liquidity value. Information related to financial statements will become a knowledge for investors about the company so it can help minimize the occurrence of information asymmetry because the information obtained by investors through financial statements is equivalent to information held by management.

Profitability and Liquidity have no direct effect on Firm Value, but have an indirect effect via Financial Distress. A company's value can't be determined solely by looking at its profitability and liquidity, because it doesn't reveal the company's entire financial health. Since the company's financial state could serve as an intermediate between Profitability and Liquidity, investors should also pay attention to the company's financial status. As a result, investors will prefer companies that do not suffer from financial distress. As a result, the findings of this study show that financial distress has a negative effect on firm value.

This study has several limitations, such as the limitations of data and scope, as well as the indicator that financial performance used to assess companies that only look at the ratio of Profitability and Liquidity which is Return on Asset and Current Ratio. Suggestions for further researchers is to use other financial ratios and indicators such as solvency ratios, turnover ratios, earning quality, earning management, growth, etc. that are more representative in measuring the Firm Value.

\section{AUTHORS' CONTRIBUTIONS}

This research contributes to companies that want to maximize their company value, also being a reference and additional literature for other researchers, related to the mediating role of Financial Distress in predicting the effect of Profitability and Liquidity. 


\section{ACKNOWLEDGMENTS}

We acknowledge Mr. Julius Yogi Christiawan and Mrs. Saarce Elsye Hatane for helping us choose the conference, guiding and also giving all the support which made us complete this project duly. Also, for authors' teamwork and hard work through the ups and downs.

\section{REFERENCES}

[1] F. Brigham and H. J. F, Dasar-dasar manajemen keuangan. Jakarta: Salemba Empat.

[2] D. A, "Financial distress: The impacts of profitability, liquidity, leverage, firm size, and free cash," Int. J. Business, Econ. Law, vol. 22(1), pp. 17-24, 2020.

[3] E. Manurung, E. Effrida, and A. J. Gondowonto, "Effect of financial performance, good corporare governance and corporate size on corporate value in food and beverages," Int. J. Econ. Financ. Issues, vol. 9(6), pp. 100-105, 2019, doi: https://10.32479/ijefi.8828.

[4] R. Sondakh, "The effect of dividend policy, liquidity, profitability and firm size on firm value in financial service sector industries listed in Indonesia Stock Exchange 2015-2018 period," Accountability, vol. 8(2), p. 91, 2018.

[5] Y. Setiawanta, A. Purwanto, and M. A. Hakim, "Financial performance and firm value lesson from mining sub-sector companies on the Indonesia Stock Exchange," J. Din. Akunt., vol. 11(1), pp. 7080, 2019, doi: doi: 10.15294/jda.v11i1.17278.

[6] M. Jihadi, E. Vilantika, S. M. Hashemi, Z. Arifin, Y. Bachtiar, and F. Sholichah, "The effect of liquidity, ;everage, and profitability on firm value: Empirical evidence from Indonesia," J. Asian Financ. Econ. Bus., vol. 8(3), pp. 423-431, 2021, doi: https://10.13106/jafeb.2021.vol8.no3.0423.

[7] I. Zuhroh, "The effects of liquidity, firm size, and profitability on the firm value with mediating leverage," KnE Soc. Sci., vol. 3(13), p. 203, 2019, doi: https:// 10.18502/kss.v3i13.4206.

[8] S. B. T, "The influence of financial ratio analysis on firm value with financial distress as intervening variable in manufacture companies listed in IDX," Int. J. Public Budgeting, Account. Financ. (IJPBAF), vol. 1(2), pp. 1-8, 2018.

[9] L. Saputri and Asrori, "The effect of leverage, liquidity and profitability on financial distress with the effectiveness of the audit committee as a moderating variable," Account. Anal. J., vol. 8(1), pp. $\quad 38-44, \quad 2019, \quad$ doi: https://10.15294/aaj.v8i1.25887.

[10] A. Kartika, H. A. Rozak, I. Nurhayat, and B. D. Bagana, "Rasio keuangan sebagai prediksi financial distress," Pros. Sendi, pp. 675-681, 2020.

[11] R. T, "The effect of financial ratios on financial distress conditions in sub industrial sector company," Account. Anal. J., vol. 7(1), pp. 25-33, 2018, doi: https:// 10.15294/aaj.v5i3.18996.

[12] S. Hermuningsih, "Pengaruh profitabilitas, size terhadap nilai perusahaan dengan struktur modal sebagai variabel intervening," J. Siasat Bisnis, vol. 16(2), pp. 232-242, 2012, doi: https://10.20885/jsb.vol16.iss2.art8.

[13] A. N. Adi, Z. Baridwan, and E. Mardiati, "Profitability, liquidity, leverage and corporate governance impact on financial statement fraud and financial distress as intervening variable," Bull. Taras Shevchenko Natl. Univ. Kyiv Econ., vol. 5(200), pp. 66-74, 2018, 2018, doi: https://10.17721/1728-2667.2018/200-9/9.

[14] T. Lesmana, "Pengaruh kinerja keuangan terhadap nilai perusahaan pada perusahaan rokok yang terdaftar di BEI," J. Proaksi, vol. 7(2), pp. 25-34, 2018, doi: https:// 10.15294/aaj.v5i3.18996.

[15] F. Fauziah and W. Jamal, "Analisis pengaruh leverage, financial performance firm size dan sales growth terhadap firm value pada perusahaan manufaktur di Bursa Efek Indonesia," Res. J. Account. Bus. Manag., vol. 4(2), pp. 125-146, 2020.

[16] G. P. Tahu and D. D. B. Susilo, "Effect of liquidity, leverage and profitability to the firm value (dividend policy as moderating variable) in manufacturing company of Indonesia stock exchange," Res. J. Financ. Account., vol. 8(18), 2017.

[17] S. A. Owolabi, U. E. Inyang, and E. Uduakobong, "Determinants of capital structure in Nigerian firms: A theoretical review," J. Account. Financ., vol. 1(1), pp. 7-15, 2012.

[18] D. A. Putra and P. V. Lestari, "Pengaruh kebijakan dividen, likuiditas, profitabilitas dan ukuran perusahaan terhadap nilai perusahaan," E-Jurnal Manaj. UNUD, vol. 2016, pp. 4044-4070.

[19] I. A, "Model prediksi financial distress dengan binary logit (studi kasus emiten jakarta islamic index)," Vurnal BPPK, vol. 8(1), pp. 1-23, 2015.

[20] T. W. Antikasari and D. Djuminah, "Memprediksi financial distress dengan binary logit regression 
perusahaan telekomunikasi," J. Keuang. dan Perbank., vol. 21(2), pp. 265-275, 2017.

[21] A. N. Kholidah, T. A. Gumanti, and A. Mufidah, "Analisis rasio keuangan dalam memprediksi financial distress pada perusahaan sektor industri dasar dan kimia yang terdaftar di BEI tahun 20112015," J. Bisnis Dan Manajemen, vol. 10(3), pp. 279-291, 2016. 